\title{
THE STATUS OF MANAGEMENT STOCKHOLDERS
}

\author{
FRANKLIN S. IVOOD
}

Writing in the first volume of the Yale Law Journal in 1891, Professor Baldwin referred to the vacillating policy which often resulted from changing corporate managements as a "real evil," and the voting trust as the remedy to which there was then increasingly frequent resort. The "evil" is as real now as then, but resort is being had to another remedy, namely, the creation of a fairly small class of voting shares along with larger classes of non-voting shares. The utilization of this remedy, however, although authorized for many years by the corporation statutes of many states, ${ }^{2}$ in certain prominent reorganizations, for the purpose of vesting voting control in certain classes of stock representing relatively small participations in the corporate assets, has recently aroused considerable comment and interest.

Such voting shares are often called management stock. The use of the word "management" is likely to be misleading, for the holders of such stock normally have nothing to do with the actual management of the corporation, but are vested solely with the right to elect all or some of the directors." So far as the provisions of the statutes themselves are concerned, the holders of management stock are in substantially the same position as the holders of stock of any other class in their relation to the corporation and the other stockholders, subject to such limitations as may be set out in the certificate of incorporation.

\footnotetext{
1 N. J. Laws 1926, c. 318, p. 533:

"Every corporation organized under this act shall have power to crcate two or more kinds of stock, any of which may be stocl: with par value or stock without par value, with full, limited or no voting powers of such classes, with such designations, preferences, relative, participating, optional or other special rights, qualifications, limitations or restrictions thercof as shall be stated and expressed in the certificate of incorporation

N. Y. Cons. Laws (Cahill, 1923) c. 60, 51 ; Onro Gen. Code (Page, 1926) $\S \S 8623-4,8669$; Mid. ANN. CoDE (Bagby, 1924) Art. 23, § 2S; Der. REv. CODE (1915) § 1927; ITASS. GEN. LaATS (1921) c. 156, § 14; VA. GE:. LAWS (1923) § 3792; MACHEN, CoRporations (1908) §570.

2 Likewise, the term "management stock" is not to be confused with "founders' or management or deferred shares" sometimes issued by English companies, usually carrying a right to share in the surplus pronits of the company after the payment of fixed dividends on the other shares and sometimes, though rarely, given special voting powers. Parsien, Cosipasiz Law (10th ed. 1916) 85-6, 347; Palmer, Company Precedents (8th ed. 1902) 491-498, 693; GORE-BROWN \& JORDAN, HANDY-BOOK OX JOINT STOCE CoMranies (27th ed. 1907) 29.
} 
At least one writer, ${ }^{3}$ however, maintains that their position is radically different, and that holders of management stock should be subjected to certain responsibilities of a fiduciary character toward the corporation and the other stockholders, viz.: (a) so to arrange the capital structure of the corporation that no class of stock shall appropriate to its benefit any of the capital contribution made by any other class of stock; (b) to act disinterestedly, and to refrain from acting in any situation in which the holders of management stock have an interest apart from that of the corporation; and (c) to bear liability jointly with the directors for corporate mismanagement unless they shall dissent from the acts complained of. These three propositions are apparently advanced less as statements of legal principles established by court decisions, or sanctioned by statute, than as suggested rules which it is felt the courts should adopt in order to guard against what are stated to be the dangers and possible abuses attendant upon the situation created by an issue of management stock.

This article is not concerned with the first of the above propositions $;{ }^{4}$ but is limited to an inquiry into the soundness of the second and third propositions. There can be no doubt that courts of equity have jurisdiction to grant relief against abuses of the power that rests in the hands of management stockholders. But it is submitted that these rules, suggested as being necessary to solve the problem, go far beyond the necessities of the fact situation which is said to have arisen. Furthermore, they are unjustified under sound principles of law and equity.

Certainly these rules involve novel and extremely onerous responsibilities to be laid upon a stockholder. We start with the fact that the management stockholder is the holder of stock,

3 Berle, Non-Voting Stock and "Bankers' Control" (1926) 39 Hanv. L. REv. 673.

4 The first proposition seems to be based upon a misconception of the true fact situation. It is impossible for management stockholders as such "to arrange the capital structure of the corporation." Any liability for an improper arrangement of the capital structure must fall upon tho parties setting up the structure, not upon a class of stock forming part of the structure so set up. This proposition is also considerably weakened by the fact that the leading decision relied upon in its support (Hodgman v. Atlantic Refining Company, 300 Fed. 590 (D. Del. 1924)) has since been reversed. 13 F. (2d) 781 (C. C. A. 3 d, 1926). In that caso the District Court had set aside as fraudulent the sale of no par stock to stockholdors, in control of the management, for a price considerably less than that paid by others, at the same time, for the same class of stock. The Circuit Court of Appeals, however, reversed the lower court's decision on the ground that the transaction complained of did not involve actual fraud. If the Court of Appeals had felt that the relationship of the parties purchasing the stock of itself constituted a constructive fraud, it would logically have affirmed the decision of the lower court. 
duly authorized by, and issued under, express statutory sanction. Why should such stock be placed in a special category, and its holders subjected to disabilities more severe than those imposed on any other stockholder, and even more serere than those generally imposed on directors?

One of the reasons urged in answer to the above question is the relatively small interest of the management stocliholder in the corporate assets. However, no basis for imposing these responsibilities upon management stock by reason of its relatively small interest in the corporate assets can be found in the statutes. ${ }^{5}$ As far as the statutes are concerned, the relative interests in corporate assets, as well as the relative voting rights, of the several classes of stock are left entirely as matters of contract among the parties organizing the corporation, to be provided for in the certificate of incorporation.

Management stock is usually held by representatives of investment bankers who have purchased bonds or other securities from the corporation and distributed them to the public, or by representatives of creditors who have aided the corporation in time of financial stress. Such holders have real interests in the welfare of the corporation, often greater than that of the few minority stockholders frequently in control. They are in fact usually the only possible representatives of the interests of security holders other than the stockholders in the management of the corporation. ${ }^{5}$ That such security holders have an interest in the management of the corporation, there can be no doubt, but it has been found impracticable to allow them to vote individually in corporate matters. Today, the average stockholder in the large corporation regards himself more as a security holder than as in any sense a responsible managing partner in the corporate enterprise, and the legal distinction between bondholders and stockholders is fast becoming a distinction unwarranted by the actual situation. This has been well brought out by Professor Isaacs and is probably the

5 Supra note 1.

"See Masslich, Financing a $N \epsilon z$ Corporate Entcrprise (1910) 5 ILL. L. REv. 70,71. Referring to the "volume of small investors which the continental countries of Europe afiord," he states:

"These peasants, of course, give no thought whatever to the goodness of the security, but rely entirely upon their bankers."

That this popular diffusion of corporate securities has now become prevalent in the United States, see the papers read before the Academy of Political Science at its meeting in New York, March 0, 102., malsing this matter the special subject of consideration.

IIn the article of Isaacs, Business Security and Legal Sccurity (1923) 37 HARv. L. REv. 201, 210, it is said:

"In legal theory the bondholder lends money to an enterprise in which he is not a participant. Whatever interest in property or control is given him is mere security for a loan. He is to be contrasted as sharply as 
reason for the popular indifference to the presence or absence of voting rights of which Professor Ripley complains. ${ }^{8}$

Another argument advanced in favor of the imposition of these responsibilities upon management stock is that new fact situations have arisen. But is the fact situation of management stock new? It will be admitted that control of corporations by a minority of the stock is no novelty, and that in the past it has been maintained by various devices, notably voting trusts. It will likewise be admitted that management stock is but a new device for the same purpose, but it is argued that it is, "on its face, subject to no limitation whatsoever." The effect of this argument would seem to be that the only difference between management stock and voting trusts is that in the latter case the legislatures have seen fit to impose certain limitations against permanent divorce of voting rights, while in the case of management stock, the legislatures have not.

These arguments against management stock are apparently based on the feeling that the statutes in question are susceptible of abuse, and in general contravene public policy. It is felt that the law cannot be blind to the fact that investment bankers may utilize such statutes for the creation of relatively small classes of voting stock purposely to achieve control without making any substantial investment. Though the writer whose propositions are referred to above concedes the prevalence among such bankers of a fairly high standard of business and banking ethics, he thinks that "the law can hardly leave investors subject to the doubtful protection of private consciences.". ${ }^{\text {To all such }}$ arguments the same answer may be made that Justice Swaze

possible with a stockholder. He is not an investor, not an owner. Ho is distinctly an outsider. At one time in the history of business such may have been the true situation of the bondholder, but it is not today. Ho is distinctly an investor. The great investment bankers, when they tako up the problem of financing an enterprise, decide between financing through bonds on the basis of a very technical study of the conditions before them, but after they have made their decision, they sell the stocks or bonds equally as investments to the public. The legal difference between stocks and bonds play only an indirect and perhaps a minor part in the decision. The investment banker's 'factor sheet' in such a problem would show more prominently questions pertaining to the salability of the issues to investors. ***

"In times of stress, the realities break through the legal fiction. Tho securities, whatever part of law their forms were taken from, are found to be in reality a mode of ownership-organization."

For similar comment see Spring, Upset Prices in Corporate Reorganization (1919) 32 HaRv. L. REv. 489.

8 Ripley, Main Street aNd Wall Street (1927) 78 et seq.

- Supra note 3 , at 676 . 
made in Warren $v$. Pim, ${ }^{10}$ to similar arguments against the validity of voting trusts:

" $* * *$ many of the arguments urged in favor of the view that voting trusts are contrary to public policy are arguments which would very properly be addressed to the legislature $* * *$

The final deduction drawn by the above writer from certain cases cited is that, "Ultimately they may be analyzed to a feeling on the part of the Court that a group in control vas acting unconscionably towards persons who had no effective voice in, and had not assented to, the corporate result." "11 With this there can be little quarrel. But proceeding then to the question whether the doctrine thus found "changes in any degree the time-honored rule that majorities may not confiscate the property of minorities in corporate matters," the writer there necessarily finds that it does. Confiscation, however, was never the extreme to which majority action would be allowed to go. The rule of conduct which the courts have enforced against majority stockholders has much more nearly proximated that truly timehonored rule of property, "sic utcre tuo ut non alicnum laedas;" or, as stated by Miorawetz:

“ $: * *$ the majority derive their powers from an implied delegation of authority from the other shareholders, and are bound to use their powers in good faith for the benefit of the whole association." 12

How much greater, if greater at all, are the duties and disabilities of management stockholders than those placed on ordinary majority stockholders? That they are as great as those imposed on a single majority stockholder or on voting trustees may be conceded, but clearly they do not approach those of directors, much less the extremes suggested in the propositions here examined.

The often-stated disability of directors to deal with the corporation arises largely from their technical relation to and identity with the corporation, involving the technical rule of agency that an agent may not deal with himself. The principles applicable to dealings by a director with his corporation, as stated by Machen, ${ }^{13}$ may be summarized as follows: (1) a director, acting as agent of the corporation, is under an absolute disability to represent the corporation in any transaction in

10 66 N. J. Eq. 353, 411 (1904).

${ }^{11}$ Supra note 3, at 681 .

12 Moratwetz, Corporations (2d ed. 1886) $\$ 477$; and see also MLACHEN, op cit. supra note $2, \S 1306 ; 7$ R. C. L. $\$ \S 285-6$.

13 IIACHEN, op. cit. supra note $2, \S 1563$. 
which he himself has an interest, except with the consent of stockholders, and (2) in dealings between the corporation and a director not as an agent, but as an individual, the director must be able to prove the utmost good faith and fairness. When there are a sufficient number of other agents or directors adequately to represent the corporation, the majority rule is that the technical disability first referred to disappears and the question then becomes chiefly one of the fairness of the transaction between the agent and his principal.14

As the corporation can act only through its officers and directors, directors should unquestionably be subjected to these technical rules. Holders of management stock, however, are clearly not within such rules, because they are not vested with the management of the corporation but only with the right to select all or. some of those in whom such management is vestednamely, the board of directors. To contend that management stockholders in their dealings with the corporation are subject to the same disabilities as directors is to ignore the fundamental differences between the positions of management stockholders and directors. The directors are the managing agents of the corporation. They are elected by the stockholders to act as agents for the corporation and, in performing the duties thus delegated to them by the stockholders, they are properly held to the responsibilities and disabilities incident to such agency.

Management stockholders, on the other hand, are in no sense agents of the corporation. They do not and cannot manage the affairs of the corporation. The statutes and charters which provide for management stock provide also that the sole power of management of the corporation shall be vested in the directors. ${ }^{15}$ If management stockholders are the agents of any one, they are the agents of the other stockholders who have expressly or impliedly delegated to them the right to elect all or part of the board of directors. Normally, the election of directors is the sole function of management stock and the stock has no voice in other corporate matters. It is logical and proper that management stockholders be held to a high degree of faithfulness in the exercise of their power to elect directors. No one can quarrel with a rule of law that requires management stock-

14 Fretcher, Corporations (1918) 3576; Howard v. Tatum, 81 W. Va. 561, 94 S. E. 965 (1918); Wabash Ry. v. Ia. \& S. W. Ry., 200 Iowa 384, 202 N. W. 595 (1925) ; cf. also Ransome Concrete Machinery Co. v. Moody, 282 Fed. 29 (C. C. A. 2d, 1922) (upholding contracts of employment of two directors where the vote of each was necessary to the validity of the other's contract); Citizens \& Co. v. Oil Co., 191 Ky. 183, 229 S. W. 88 (1921); infra note 17.

15 Morawetz, op. cit. supra note 12, $\$ 475 ;$ N. J. Comp. Stat. (Cum. Supp. 1924) c. 47, § 12; N. Y. CoNs. Laws (Cahill, 1923) c. 60, §60; O110 Gen. Code (Page, 1926) § 8660 . 
holders to use their power fairly to elect directors who in their honest judgment are qualified properly to manage the affairs of the corporation, nor with a rule that prohibits management stockholders from exercising their power in their own interests, or from putting dummies, incapable of independent judgment and action, on the board.

But to go beyond this-to subject management stocliholders to technical disabilities and responsibilities imposed upon directors as agents of the corporation, although management stockholders are not in fact such agents, and cannot be such without violating the one function, that of electing directors, imposed upon them-is an extension of the fiduciary doctrine beyond all limits justified by logic, reason or legal precedent. Of course, if a management stockholder oversteps the boundary of his proper function, and becomes in fact a managing agent of the corporation, either directly or through dummies on the board who are controlled and dominated by him, he subjects himself to the disabilities and responsibilities of a director; but, in the absence of such a showing - and it should be borne in mind that whether or not directors are dummies or are controlled or dominated by management stockholders is always a question of fact, and that they are not such merely because they were elected by the management stockholder's ${ }^{15}$ - there is no justification for a rule which would apply to him the technical disability of a director and prohibit his dealing with the corporation.

In this connection a word may perhaps be inserted as to the

16 Int. Stevedoring Co. v. Frank Waterhouse \& Co., 129 Wash. 451, 225 Pac. 420 (1924); see Cowell v. MicMillin, infra note 20, at 42:

"It is insisted, however, that the directors were dummies when they voted for the renewals, because they were elected by the vote of MeMillin, the holder of the majority of the shares of stocl. This must be considered in connection with all other evidence. In the sense that they owed their positions as members of the board to MreMillin, complainant is correct; but, in the sense that they were mere creatures, villing or obligated to do IIcMillin's bidding, and to aid him in executing fraudulent designs, or knowingly to do any act beyond the law, or that was unfair or oppressive, or against the defendant company's interests, the contention is without merit. It is needless to do more than to state the elementary rule that the majority of the stockholders usually elect the direetors, and that a corporation is represented by its directors, not by the stockholders. So, it is to the directors of a company that the management of its concerns and the power to make contracts are given. Nor does the fact that a director only owns one share in a corporation ordinarily alter the general rule by lessening the power vested in him as a director, the board of directors being expressly or implicdly authorized to do all acts which are proper to carry out the corporation's chartered purposes."

See also Levy v. Equitable Trust Co., 271 Fed. 49, 56 (C. C. A. Sth, 1921); Atlantic Ref. Co. v. Port Lobos Petroleum Corp., 2SO Fed. 984, 939 ( D. Del. 1922). 
likelihood of such control. The directors elected by the management stockholders will undoubtedly for the most part be individuals well known to, possibly business associates of, the latter -as a concession of considerable practical importance some of the directors so elected may even represent opposing factions or groups of the other stockholders-but a majority, if not all, of the directors of a corporation large enough to have warranted the creation of management stock will be men whom one would hesitate to label ipso facto the dummies of another, merely by r'eason of their election by that other. The result is that the indulgence of a presumption of control by the management stockholders without any proof of the fact would, in addition to being without legal or logical foundation, often prove ridiculous in its application.

Even if the management stockholder be regarded as the agent of the other stockholders for the purpose of electing directors, there is no rule of law which prevents him from dealing with persons other than stockholders. And, as long as the corporation is managed by a board of directors who, though elected by the management stockholders, are capable of independent judgment and action, the corporation is a third person. The courts will not disregard the fact that the corporation is a separate entity from its stockholders until in a particular case this well-established relationship is shown to be the means of fraud or unfair dealings. These considerations are no more to be thrown aside, and a reign of terror invoked by providing a technical rule of disability in the case of the management stockholder, than in the case of a voting trustee, or of a single majority stockholder, or of a few minority stockholders in control.

The present tendency of the courts is undoubtedly to relax the rule imposing a technical disability, even in its application to directors, and to hold the directors only to the test of good faith and fair dealing if the corporation is represented by n disinterested majority.17 But no decision has been found, even in jurisdictions which impose upon directors an absolute disability to deal with the corporation, which imposes a similar disability upon a stockholder, though the stockholder be a majority stockholder, or in a position of dominance over the affairs of the corporation. The maximum responsibility which the courts have put upon stockholders in a position of dominance has been that of good faith and fairness in their dealings with

17 MACHEN, op. cit. supra note $2, \S \S 1572,1573$; MoRAWETz, op. cit. supra note 12, § 521; FLETCHER, op. cit. supra note 14, at 3505. See Rogers Powers, Duties and Liabilities of Corporate Directors (1915) 12 OHo L. REP. 619, 623, 629. 
the corporation, ${ }^{15}$ a rule which disregards the fact of the corporate entity and treats such stockholders as fiduciaries to a limited extent, but which falls far short of prohibiting dealings between such stockholders and the corporation. Niachen approves of this requirement of fair dealing on the part of such stockholders, "whether or not it be sound in theory," 19 thus apparently recognizing the inherent difficulty of justifying any fiduciary relationship between a stockholder and his corporation.

The second of the suggested propositions mentioned at the outset would require the management stockholders "to iefrain from acting in any situation in which they have an interest apart from that of the corporation." This rule would, of course, bring the holders of management stock under the absolute disability which only a few jurisdictions impose upon directors, viz., that of an agent dealing with himself-a result which, as shown above, is wholly inapplicable to the fact situstion of management stock, since management stockholders are not agents of the corporation. Further, this rule goes far beyond the ordinary: rule of a fiduciary's responsibilities in dealing with his cestui in matters outside of the scope of the agency or trust. Far from imposing such an absolute disability upon stockholders in a position of dominance, many courts have held that even directors may deal with the corporation, ${ }^{2 n}$ may, and often should,

\footnotetext{
1s Kavanaugh v. Kavanaugh Knitting Co., 226 N. Y. 185, 195, 129 N. E. 148, (1919) :

"When a number of stockholders constitute themselves, or are by law constituted, the managers of corporate affairs or interests, they stand in much the same attitude towards the other or minority stodlholders that the directors sustain, generally, towards all the stoclholders, and the law requires of them the utmost good faith."
}

To similar effect see MIACHEN, op. cit. supra note $2, \S 1807$ :

"Where one class of shareholders has no vote or voice in the corporate management, there is the stronger reason for holding that the other shareholders stand in fiduciary relation toward them."

Also Williams, Responsibility of Corporate Control (1926) 12 VA. L. Rev. 563.

19 MLACHEN, op. cit. supra note $2, \S 1306$.

${ }^{20}$ Cowell v. MICMillin, 177 Fed. 25 (C. C. A. 9th, 1910). In this case the defendant, president and majority stockholder, bought a patented barrel-making machine and contracted with his corporation for the sale of its produce. The court held that as the contract was fair and entered into for the corporation by a disinterested majority it could not be aroidcd. The point was also made in the case that at the time of renewals of the contract the majority of the directors held but one share of stocls cach, having sold all the rest of their stock to MicMillin. The court held that this did not make them dummies of his, however; that the management was still with them, although they were selected by him.

MORAWETZ, op. cit. supra note 12, \$ 528; FLETCHER, op. cit. supro note 14, at 3525 . 
assist it in refinancing, ${ }^{21}$ and that corporations controlled by the same stockholders may deal with each other except in the case where the presence of a majority of interested directors on the board of each corporation subjects them to the technical disability of an agent dealing with himself. ${ }^{22}$

The dangers attendant upon separation of control from equitable ownership can be guarded against without creating any such severe rule of fiduciary relationship as that suggested. Equity will not permit the powers held by management stockholders to be used as instruments of fraud or unfair dealing. If, through identity of interests between management stockholders and directors, or through the actual domination or control of directors by management stockholders, the latter become in fact the managing agents of the corporation, then admittedly they may not deal with the corporation without subjecting

${ }^{21}$ Sanford Tool Co. v. Howe, Brown \& Co., 157 U. S. 312, 15 Sup. Ct. 621 (1894) (the stockholders authorized the extension of a mortgage to. its directors to secure present and future advances. The Court uphold their enforcement of the mortgage as against creditors); Minn. Loan \& Trust Co. v. Peteler Car Co., 132 Minn. 277, 156 N. W. 255 (1916) (mortgage to majority directors was upheld); Schnittger v. Old Homo \& Min. Co., 144 Cal. 603, 78 Pac. 9 (1904); New Memphis Gas Lt. Co. Cases, 105 Tenn. 268, 60 S. W. 206 (1900); Irving Bank Columbia Trust Co. v. Stoddard et al., 292 Fed. 815 (C. C. A. 1st, 1923) (the plaintiff bank creditor nominated three of the five directors of the corporation and now sues to uphold agreements made with the corporation regarding subsequent financing. The court upheld these agreements as fair).

22 U. S. Rolling Stock Co. v. R. R., 34 Ohio St. 450 (1878) (this case concerned the right to avoid a contract between two corporations having five common directors, entered into by one of them at a meeting of the directors attended by eight of its thirteen directors, two of the eight being also directors in the other corporation. The court held the contract could not be avoided); Aldine Mfg. Co. v. Phillips, 129 Mich. 240, 88 N. W. 632 (1902); Int. Stevedoring Co. v. Frank Waterhouse \& Co., supra noto 16 (attempt was made by the trustee in bankruptcy of the defendant company to avoid the foreclosure of a pledge by the latter to the plaintiff company, on the ground of F. W.'s adverse interest in the pledgee corporation. Tho court held that the pledge was not void solely on the ground of the interlocking directorate and that although the personal interest of $F$. W. and possibly his son were actually adverse, still the interests of the othor common directors elected by them were not necessarily so and the contract would stand); Farmers' State Bank v. Haun, 30 Wyo. 322, 222 Pac. 45 (1924) ; 7 R. C. L. § 461; FLETChER, op. cit. supra note 14, 3610, 3634-5, 3641; Morawetz, op. cit. supra note 12 , \& 530. Some cases uphold the contract, if fair, even where there was a majority of common directors on each side. Hill v. Gould, 129 Mo. 106 (1895) ; Teller v. Tonopah \& G. R. R., 155 Fed. 482 (E. D. Pa. 1907) ; South Side Trust Co. v. Washington Tin Plato Co., 122 Kan. 469, 252 Pac. 237 (1916); Leavenworth v. Chicago \& R. R. Co., 134 U. S. 688, 10 Sup. Ct. 708 (1889); $c f$. Globe Woolen Co. v. Utica G. \& El. Co., 224 N. Y. 483, 121 N. E. 378 (1918) (avoiding contract between two corporations found unfairly induced by one dominating common director). 
themselves to the same responsibilities and disabilities to which directors are subject. ${ }^{23}$ These responsibilities and disabilities arise, however, not by reason of the fact that they are management stockholders, but because of the identity between the direetors and the management stockholder's in such case.

The mere fact that the directors are elected by the management stockholders does not, howerel, in itself make them dummies. ${ }^{24}$ Nor does it make the management stocliholders direetors. In this respect, the holders of management stocli cannot be logically distinguished from two or three individual majority stockholders, or from the small percentage of minority stockholders actually in control of every large corporation whose stock is widely distributed. Still less can the holders of such stock be distinguished from voting trustees. The disparity of actual interests in the corporate assets between the management stockholders and the other stockholders is certainly no greater than that between voting trustees and the holders of voting trust certificates. Yet the right of such majority stochholders, such minority stockholders, and such voting trustees, $;=$ to deal with the corporation seems not to have been seriously questioned.

The propriety and usefulness of voting trusts have become generally recognized. Since before the time of Professor Baldwin's article, referred to at the outset, the voting trust has been the orthodox means of insuring control over the management of a corporation, particularly in cases where the corporation has been in financial difficulties and the persons furnishing new money to it are justifiably insistent upon being assured that its affairs will be handled by men whom they know to be capable. ${ }^{\text {a }}$ In the lists of voting trustees acting under the voting trusts of stocks of numerous railroads and other large corporations, there are often found representatives of the banling houses who sponsored the sale of the securities of such corporations to the public, and who continue to handle the financing of such railroads or other corporations, while their representatives serve as voting trustees. ${ }^{27}$ There has been no suggestion that voting trustees may not deal with the corporation, and indeed the application of any such doctrine to voting trusts would be seriously disturbing to the financial position of corporations whose stocks are today held under such roting trusts.

Yet no closer analogy to management stoclholders can be

${ }^{23}$ FLETCHER, op. cit. supra note 14, at 6783 , and cases there cited; 7 R. C. L. $\$ 461$.

24 Supra note 15.

25 Cushing, Voting Trusts (1915) 28, 32, 56.

${ }^{26}$ Ibid. 24.

${ }^{27}$ Ibid. 45, 56, and see the roting trustees named in the forms of Voting Trust Agreements given, ibid. 148, ct seq. 
found than that of voting trustees. The duties of both are very similar-"the practical tendency has been to confine the functions of the voting trustees to the choice of a board of directors, the receipt of dividends and the distribution of amounts so received, and the discretionary power of terminating the trust" 20 - the chief distinction being that management stockholders are not troubled with the collection and distribution of dividends, and that the duration of their stock is fixed in the charter. The principal complaints directed now against management stock are likewise very similar to those which were originally directed against voting trusts, viz., that individual stockholders are deprived of the benefit of the deliberation and judgment of their fellow stockholders in the annual election of directors, that control is centered in a small group without any real financial interest in the corporation, and usually with ulterior motives to serve, and finally, that the voting power is separated from the beneficial ownership of the stock and of the corporation..$^{20}$ The result aimed at by both voting trusts and management stock is the same. Continuity and efficiency of management of the corporation are demanded by some group of individuals or interests, usually as security for money loaned, and are conceded by the corporation and its stockholders.

With regard to voting trusts one writer has said: ${ }^{30}$
“*** necessarily it was found that there must be cases in which voting trusts should be allowed $* *$ for example, where money is borrowed and a voting trust is created to continue until the loan is paid. No court has ever condemned such a voting trust and it is safe to suppose that such a trust will never be condemned. Economic necessity in such in- stance is too clear. Many a corporation in urgent need of funds has found itself where it could not borrow the money which it was compelled to have unless the voting power over its stock and the corresponding control over its affairs were placed in the hands of the lender or a person designated by the lender, to continue there so long as the loan was out- standing."

The' contract made by stockholders in the certificate of incorporation providing for management stock under legislative sanction should not be of less dignity or less binding force than the contract among stockholders setting up a voting trust. It may, of course, be objected that the latter is limited in duration, either by practice or by statute, whereas management stock is

28 Ibid. 14.

29 Ibid. 103 et s'eq.; Finkelstein, Voting Trust Agreements (1926) 24

Mich. L. Rev. 344.

${ }^{30}$ Marion Smith, Limitations on the Validity of Voting Trusts (1922) 22.

CoL. L. Rev. 627, 630; Cushing, op. cit. supra note 25, at 107. 
by statute unlimited in duration. This objection, however, fails in cases where the life of the management stock is limited to a particular time, as is likely to be the case where the management stock is issued as part of a plan of reorganization to insure continuity and efficiency of management during the life of the securities issued upon the reorganization.

The fact that large corporations with widely scattered stoels are usually controlled by a very small minority of stocliholders, and the ease with which such minority control has been obtained, has been the subject of considerable comment. ${ }^{31}$ This very ease of minority control, with its resultant dangers not only to the holders of bonds and notes of the corporation, but also to the other stockholders, is a strong inducement to those undertaling any considerable corporate financing to insure against the disastrous consequences of a selfish exercise of such minority control, by the issuance of management shares or otherwise.: Especially is this true in the case of investment banking houses who recognize their obligation to the public purchasing the securities distributed by them. The following comment illustrates the bankers' position in this connection: ${ }^{33}$

"The reviving of a helpless concern is usually, and naturally, entrusted to a banking firm or a group of banliers. They or their friends are expected in the end to marliet the securities of the reorganized company and they are entitled to take all proper steps both for protecting their customers and for insuring correct management of a company of which they are regarded as financial sponsors. Their possible profits in controlling future underwritings are negligible as compared with the effect on their business of having incompletely managed a futile reorganization."

31 In the February, 1926, issue of "The Index," published by tha New York Trust Company, attention is called to this case of minority control (p. 3) :

" $* * *$ with a dozen owners, probably $51 \%$ will be necessary for dominance. With 300,000 scattered holdings, a possible 15 or $20 \%, i$ of the votes can never be overmatched at an election."

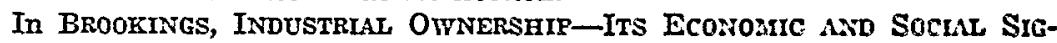
NIFICANCE (1925) 9 , attention is called to the same fact and quotation is made from the letter of the president of a large national corporation to the effect that out of 8069 stockholders over $90 \%$ own less than 100 shares and the directors and their friends and relatives own and control less than 10\%. CusHing, op. cit. supra note 25, at 14 ct scq; Baldwin, Foting Trusts (1891) 1 Yale LaW JourNal 1.

32 MORAWETz, op. cit. sappra note 12, at 495:

"Not infrequently, persons who agree to advance money to a corporation expressly stipulate for a voice in the board of directors, so that they may be able to supervise the faithful application of the money advanced and can watch for their own security."

Irving Bank Columbia Tr. Co. v. Stoddard, supra note 21.

33 Cushing, op. cit. supra note 25 , at 27 ; see also supra note 6 . 
No one has ever questioned the right of majority stockholders, minority stockholders or voting trustees to purchase the securities of their respective corporations, both directly and from third parties, to resell such securities to the corporation at a fair profit, and generally to deal with the corporation, so long as there is not an identity of interests with, or actual domination of, the majority of the board of directors. ${ }^{34}$ It is frequently stated that a director must not profit at the expense of his corporation, and that if he does, he may be made to account to the corporation for such profit. This general statement is not strictly true even in the case of a director, ${ }^{35}$ and $a$ fortiori cannot be true in the case of a management stockholder. Professor Warren states: ${ }^{36}$

"There is no rule that a director may never purchase from third persons the obligations of the corporation for his own account, but he must not compete with the corporation in the purchase of its obligations."

It is only when the individual director infringes the foregoing rule of not competing with the corporation that he may be compelled to account to his corporation upon a later sale to it. In accordance with the rules underlying fiduciary relationships as stated by Machen, ${ }^{37}$ where the person in a fiduciary relation sells to his cestui, in a transaction not within the limits of the agency or trust (or in the case of a director, where the corporation is adequately represented by other directors), he owes that cestui only the duty of fair dealing. ${ }^{38}$ The price which the fiduciary may have paid for the property in question is immaterial, and in only the few cases where the director or the fiduciary in question may be said to have purchased the property on behalf

34 Supra notes 19, 20, 21.

35 FLETCHER, op. cit. supra note 14, at 3507 et seq., discussing the theoretical difficulties of holding a director to the responsibilities of a trusteo. 36 (1921) 34 HARv. L. REv. 282, 296.

${ }^{37}$ Supra note 13.

38 Howland v. Corn, 232 Fed. 35,43 (C. C. A. 2 d, 1916). It was held in this case that the receiver could not require an accounting from three of the five directors of a bankrupt corporation for their profits on sales of property to the corporation so long as made fairly (one of the three directors owned one piece so sold and the two others were majority stockholders in the corporation selling the second); Hannerty v. The Standard Theatre Co., 109 Mo. 297, 19 S. W. 82 (1891).

FLETCHER, op. cit. supra note 14, § 2304 :

"If a director or other officer purchases property, being at the time under no duty to purchase for the corporation, he may afterwards sell it to the corporation, if it is represented by other officers, without disclosing what he paid for it, and if there is no fraud, he will not be compelled to account for the profit he may make in the transaction."

Morawetz, op. cit. supra note 12, §.521; (1913) 13 Cor. L. Rev. 432. 
of the corporation or cestui can the latter require the fiduciary to account to it for any profits. ${ }^{33}$ This point is well brought out by Mr. Kenneth V. Riley: ${ }^{40}$

"It is everywhere agreed that a director occupies a fiduciary relation to his corporation. But although the courts and writers speak of the director as a trustee for his corporation and for the body of stoclholders, they are not in accord as to the extent of the trusteeship or of the duty this imposes upon him with respect to transactions where his individual interests may rival the interests of this corporation. It was contended in the recent Illinois case that the mere fact that an investment would be beneficial to the corporation, the corporation being in a position to take advantage of it, raises a duty in the director to offer it to his company before taking it for himself. Statements in textbooks and dicta of judges appear to support this contention, but the cases therein cited do not bear them out. For in each of the cases cited there was not only an investment which would have been to the interests of the corporation, but the corporation, by its nature or otherwise, had been actually committed to the investment, to the director's knowledge, so that he was under a specific duty to procure it for his corporation or at least to give it the first opportunity to make the investment."

The same distinction is made by the Massachusetts Court in the case of Parker v. Nickerson: ${ }^{11}$

"But if he did not originally buy the coal for the purpose of selling it to the Company, and did not buy it at a time when it was his duty as treasurer to buy coal for the Company, it is difficult to see how he can be treated as the agent of the Company in making the original purchase. If the defendant rightfully bought the coal on his own account and then subsequently, as agent of the company, bought the coal from himself, the contract could undoubtedly be rescinded by the company if it could restore the coal, and if it could not, the company would not be bound to pay the price fixed by the defendant but only bound to pay what was a reasonable price at the time; but this is very differcut from holding that it is only bound to pay what the defcudant paid for it some months before."

The non-disclosure of the fiduciary's interest may give the corporation dealing with him the right to rescind, but such rescission having become impossible, the recovery to be had by the corporation is not all profits made by the fiduciary but only

39 FLETCHER, op. cit. supra note 14, at 3524.

40 (1920) 4 MIINN. L. REv. 513.

11137 Mass. 487, 497 (1884). 
the difference between the price paid by the corporation and the fair value at the time of the purchase by it.2

The foregoing authorities show that, even if we admit an extraordinary duty, even that of a director upon the management stockholder, the only limitation which would be placed upon transactions between him and his corporation would be

12 Supra note 34; Burland v. Earle, [1902] A. C. 83, 94, 98; In Ro Crpo Breton Co., 29 Ch. Div. 795, 805 (1885); see Zeckendorf v. Steinfiold, 12 Ariz. 245, 261, 100 Pac. 784, 790 (1909):

"The law is that one may not purchase and hold, as his own, proporty which he is in duty bound to purchase and hold for another. * * This rule applies to officers and directors of a corporation, as to othor persons sustaining fiduciary relations to others. . Whether in any case an officer of a corporation is in duty bound to purchase property for tho corporation or to refrain from purchasing property for himself, depends upon whether the corporation has an interest, actual or in expectancy, in the property or whether the purchase of the property by tho offlcor or director may hinder and defeat the plans and purposes of the corporation in the carrying on or development of the legitimate business for which it was created ***. We think the rule as thus stated is as broad as the authorities will sustain."

Supra note 19; Board of Com. of Tippecanoe County v. Reynolds, 44 Ind. 509 (1873); Highland Park Inv. Co. v. List, 27 Cal. App. 761, 161 Pac. 162 (1915). Machen states this refusal of equity in such a caso to compel an accounting by the directors or trustee to be an arbitrary oxcoption in England. See MACHEN, op. cit. supra note $2, \$ 1609$. Tho principles underlying the rule would appear to be correct, howover, and the foregoing and numerous other cases would bear out the distinction here contended for. Cf. Redhead v. Parkway Driving Club, 148 N. Y. 471, 42 N. E. 1047 (1896) ; Nat. Mfrs Co. v. Bird, 97 N. J. Eq. 242, 127 Atl. 819 (1925) (in each case the defendant directors wero required to account for breach of an express duty to buy or sell as agents of tho corporation). The same distinction is made in Harts v. Brown, 77 Ill. 226 (1875) (the directors there bought up the bonds of the corporation and foreclosed the mortgage. The court required them to account to tho complaining stockholders only for the sale of corporation property in excess of that required to pay the amount due on the bonds, for in the sale of such excess they themselves sold as agents of the corporation and must account). Cases allowing directors to purchase corporate securities and claims from third persons at a discount and to enforce them the tho face amount, would seem to go on much the same grounds. See Camden Srfo Dep. \& Tr. Co. v. Citizens Cold Storage Co., 69 N. J. Eq. 718, 61 Atl. 520 (1905); Inglehart v. Hotel Company, 32 Hun 377, 383 (N. Y. 1884); Seymour v. S. F. C. Ass'n, 144 N. Y. 333,39 N. E. 365 (1895). (particularly at 342 et seq., 39 N. E. at 366 , et seq., at which Finch, J., clearly expresses the above distinction); Forest \& Co. v. Gade, 55 Ill. App. 181, 197 (1894).

From these cases it would seem that if at the time of the alleged trustee's purchase in question he was delegated to purchase on behalf of the corporation or the property was essential to its business, or the securities or claims purchased were past due, he then must account to it for any profits made to him from the resale to the corporation. Othorwiso he can only be compelled to account to the corporation for the difforonco between the fair value at the time of re-sale and the price paid by tho corporation. 
the duty of fair dealing. There is no support for the contention that he cannot deal with the corporation or that, if he does, he must account for all profits derived therefrom.

One of the most serious practical effects of an absolute disability on the part of the management stockholders to deal with the corporation would be to prevent investment banliers holding management stock, created in the interest of the investing public, from handling new financing of the corporation in question or from aiding in any way in its financial affairs. The necessity to every large corporation of continuously securing new capital, and the desirability of its having a definitely established banking house connection, are everywhere recognized. It is obvious that under these circumstances, if the bankers of such corporation cannot deal with it because of their ovnership of its management stock (and in all too many instances control of the corporation by the bankers has been necessitated as a safeguard against the repetition of previous financial reverses),

${ }^{13}$ See the numerous instances cited in Cushing, op. cit. supra note 25 , at 78 , et seq. An interesting example of the financial dificulties of a large corporation is found in the Westinghouse reorganizations detailed in Dewing, Corporate Promotions and Reorganizitrons, (1914) 197; 198:

"Both followed crises in the company's history, resulting directly from a too rapid investment of capital in fixed assets and indircetly from an unconservative business policy. At both times, the financial stability of the company was wrecked through its lack of working capital. The business was never an economic failure in the sense that it did not earn adequate interest and profits. On the contrary, the earnings were abnormally great and the dividend disbursements, in the periods immediately before, disproportionately high. The methods employed to secure relief were identical in the two cases also. $\Rightarrow \Rightarrow$ The positive expedients were the same; the merchandise creditors and bankers funded their debts into stock. ***

"It is only fair to those who successfully brought the Westinghouse Company through the crises of 1907 to outline briefly the result of their policy. When the receivers were discharged in the autumn of $190 \mathrm{~S}$, a new management assumed the control of the company, for the merchandise crcditors and the bankers had been unwilling to malie the sacrifice which the reorganization involved, unless they were assured that the errors in financial judgment and the recklessness in the declaration of dividends which had brought disaster to the Westinghouse Company were not to be repeated in the future. They took the management of the Company out of the hands of its former stockholders, undertook to administer it themselves on the basis of a greater conservatism. A new board of diretors was chosen, consisting of 16 men who had been prominent during the rceeivership of the company. Its members were selected from among the banliers', the merchandise creditors' and the stockholders' committees, and their representatives."

See also Kidd v. Traction Co., 74 N. H. 160, 66 Atl. 127 (1907), and Winsor v. Commonwealth Coal Co., 63 Wash. 62, 114 Pac. 908 (1011), in both of which cases the persons loaning the moneys stipulated for control of the corporations. In the former case the bankers in agreeing to the finaneing required by the defendant corporation stipulated for the election by 
the corporation would be cut off from the very people who are best acquainted with its needs and resources, most interested in its welfare and most likely to accord it advantageous terms.4

Before any reputable investment bankers will undertake any extensive financing of a corporation, the corporation is subjected to a careful examination from every angle.45 Legalities are carefully investigated; titles are searched; and complete audits are made. Must the corporation, each time it issues securities, be required to seek new bankers and again bear the very considerable expense of new appraisals, new investigations, now audits? ${ }^{46}$

It is obvious that the suggestion that management stockholders must refrain from acting in any cases where they are interested attaches to such stockholders disabilities far more onerous than those applicable to persons admittedly in a fiduciary relation to a corporation. ${ }^{47}$ No such disability would attach to an individual majority or minority stockholder in control, or to voting trustees or even to an individual director. ${ }^{49}$

them of three of the five directors on its board, and the actual contract was not executed or performed until sometime after these three mombers had assumed office. The appellate court stated in the first case:

"The control (by the bankers) which the Court made use of in applying the doctrine of constructive fraud to the case, resulted from tho contract; the contract did not arise from the control."

44 MoraweTz, op. cit. supra note 12, at 495; Irving Bank Columbia Trust Co. v. Stoddard, supra note 21; Warren v. Pim, sutpra note 10 (Swaze, J., commenting on frequent desirability of continuity of management as security) ; Hill v. Walville Lumber Co., 114 Wash. 476, 195 Pac. 249 (1021); Cook, Corporations, (8th ed. 1923) 2198; Fletcher, op. cit. supra noto 14, at 3603, quoting Justice Miller in Twin-Lick Oil Co. v. Marbury, 91 U. S. 587,589 (1875), as follows:

"While it is true that the defendant, as a director of the corporation, was bound by all those rules of conscientious fairness which courts of equity have imposed as the guides for dealing in such cases, it cannot bo maintained that any rule forbids one director among several from lonning money to the corporation when the money is needed, and the transaction is open, and otherwise free from blame. No adjudged case has gone so far as this. Such a doctrine, while it would afford little protection to the corporation against actual fraud or oppression, would deprive it of the aid of those most interested in giving aid judiciously, and best qualified to judge the necessity of that aid, and of the extent to which it may safely be given."

45 See Masslich, op. cit. supra note 6. To the same effect see Isaacs, op. cit. supra note 7, at 208.

$46 \mathrm{Mr}$. Masslich in his article, supra note 6 , mentions the complaint on the part of small corporations of their inability to afford these exponses and consequently their inability to interest investment bankers.

47 Fietcher, op. cit. supra note 14, at 3553, 3602-3.

48 Ibid. 3602-3; Stuart v. Larson, 298 Fed. 223, 225 (C. C. A. 8th, 1924); see also Cook, Fraud and Ultra Vires in Reorganization (1924) 10 A. B. A. J. 780,785 . There is authority for the proposition that 
If the management stock can be shown to be actually in control, if the directors are actually dummies, certainly the transaction should be subject to the most searching scrutiny. Further than this, neither logic nor principles of equity would seem to require any such rule.

As for the third suggested proposition-that the management stockholders should be held jointly liable with the directors for mismanagement-it is submitted that in accordance with the principles stated herein the management stockholders would of course be jointly liable for the mismanagement in any case in which it could be shown that they had been jointly responsible, ${ }^{19}$ as in the case of other joint tortfeasors, but not otherwise. In the absence of a showing of conspiracy or election of incompetent directors by voting trustees or by individual majority or minority stockholders of the corporation, no one would consider charging them with such joint liability purely becruse of their selection of the directors. The control over directors exercised by management stockholders is no greater in theory or in practice than that exercised by these others with power to elect all or a majority of the board.50 Bankers as such, and as owners of management stock, should not be subject to a liability so much greater than that of others in analogous positions.

To summarize, the legality of the creation of rnanagement stock does not appear to be questioned. The creation of nonvoting stocks has long been expressly authorized.51 Consequently the distinctions stated herein between the holder's of such stock and directors must be conceded, and in the absence of a showing in each case of an actual situation destroying this distinction, it must stand.52 As shown above, the fact situation underlying, and emphasized as distinguishing, management stock is not substantially different from the fact situation underlying voting trusts, and the adverse comments directed against management stock are strikingly similar to those once directed against vot-

this disability would not even attach to a majority of the directors. FLETCHER, op. cit. supra note 14, at 3610 .

\$9 Kavanaugh v. Kavanaugh Knitting Co., supra note 18.

50 MTORATETZ, op. cit. supra note $12, \S 475$ :

"If the charter of a corporation provides that particular agents shall exercise certain powers, or do certain acts, the majority have no right to interfere with such agents in the exercise of the poviers entrusted to them; and it is immaterial that such agents were appointed by the majority, and that the majority have authority to appoint their successors. Under these circumstances, the majority can exercise merely an appointing power, and control the management of the company's business by the election of such oficers as will carry out their duties."

And see supra notes 16, 20.

51 Supra note 1.

52 Supra notes 14, 16, 20, 46, 50. 
ing trusts. It is safe to say, therefore, that in the same way that the attitude toward voting trusts has gradually changed and their usefulness has become generally recognized, it is probable that as the true nature of management stock is more studied and appreciated, any initial hostility will wane. The general principles of equity will be found a sufficient safeguard, without the invocation of new rules of disability which, in their application, would be highly impracticable and unfair, as well as prejudicial to the best interests of the corporation and its stockholders. 